\title{
Comparison of particulate matter in combustion of wood chips and sawdust at nominal and reduced output
}

\author{
Alexander Čaja ${ }^{1, *}$, and Nikola Kantová ${ }^{1}$ \\ ${ }^{1}$ University of Žilina, Department of Power Engineering, Univerzitna 1, 01026 Žilina, Slovakia
}

\begin{abstract}
Biomass has been still on the rise in recent years in the world. But combustion of biomass led to the increase of emissions in the atmosphere. Mainly in winter time is formed a large amount of particulate matter. They have adverse impact on our health when human breathes them. This is a reason why is important to produce low level of these emissions. However, several aspects impact on their formation. This article examines impact of type of fuel and operation of heat source on PM formation. It compares particulate matter from combustion of wood chips and sawdust at nominal and reduced output.
\end{abstract}

\section{Introduction}

As a source of heat and energy, biomass has been still on the rise in the recent years in the world [1]. We distinguish different types of biomass, such as wood chips or wood sawdust. Wood chips may consist of wood, bark, needles, green leaves, twigs and undressed admixture [2]. The main source of sawdust is chipboard production. Both of fuels are mainly suitable for combustion in boilers with higher outputs [3]. During the combustion of these fuels are formed emissions. Under ideal conditions, complete combustion of carbon would result only in generation of carbon dioxide $\left(\mathrm{CO}_{2}\right)$ and water vapour. Any products other than $\mathrm{CO}_{2}$ are often called products of incomplete combustion and include particulate matter (PM) and gases [4]. The most important parameters for complete combustion conditions are a high combustion temperature, a sufficient amount of combustion air supply, and adequate mixing of combustion air and fuel gas $[5,10]$.

Particulate matter could be a mixture of solid particles and liquid droplets, which vary in concentration, composition (can contain various organic and inorganic compounds) and size distribution [4].

Particulate matter has adverse impact on our health when human breathe them. This is a reason why is important to produce low level of these emissions. Their amount depends on the method of the combustion process, the type, shape and moisture content of fuel, the fuel distribution in the furnace, a dose of fuel, quantity, temperature and speed of the combustion air and so on $[6,7]$. This paper examines impact of type of fuel and operation of heat source

* Corresponding author: alexander.caja@,fstroj.uniza.sk 
on PM formation. It compares particulate matter from combustion of wood chips and sawdust at nominal and reduced output.

\section{Material and methods}

Fuels, wood chips and sawdust were tested on experimental heat source with the cyclone separator in the chimney tract. This separator was installed because of capture of particulate matter. Combustion of these fuels was realized at nominal output of $450 \mathrm{~kW}$ and then at reduced output of $120 \mathrm{~kW}$. Particulate matter was obtained by gravimetric method using by sampling probe Figure 1 placed in the chimney behind the cyclone separator and caught on a membrane filter,

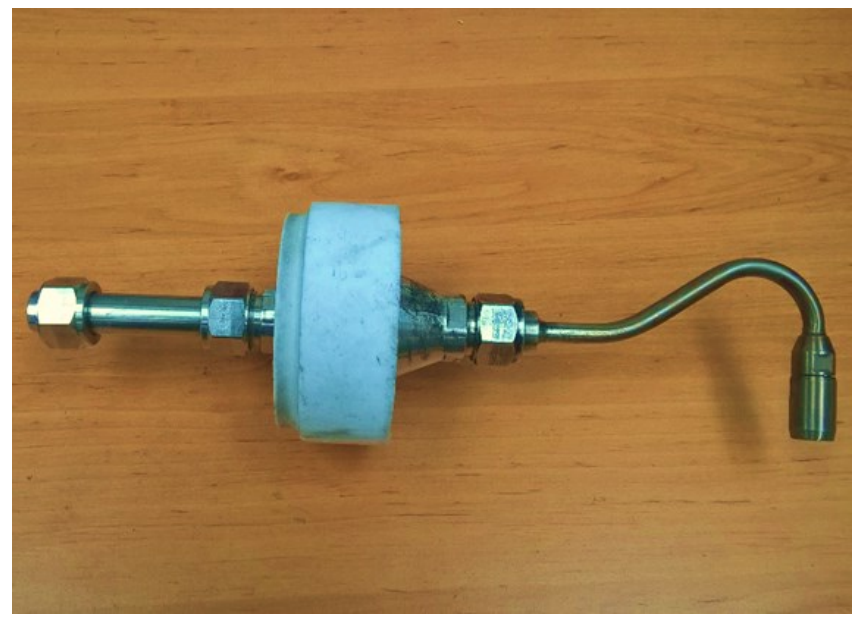

Fig. 1. Sampling probe.

There was determined the amount of particulate matter from the weight of membrane filter before sampling and after sampling. For this evaluation was used the drying and accurate analytical weighing scales. During sampling, there was ensured isokinetic condition Figure 2.

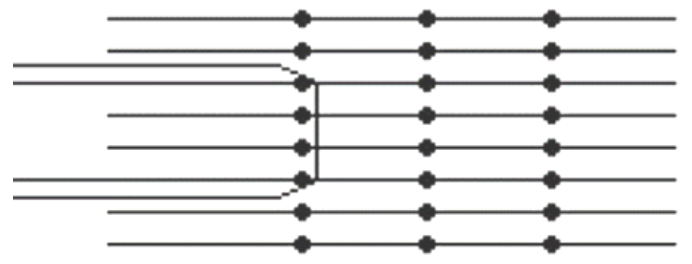

Fig. 2. Isokinetic condition.

It means that velocity of gas entering the sampling probe is exactly equal to the velocity of the gas stream. Then the concentration in the entering of the sampling probe is the same as the concentration in gas stream [8].

\section{Results}

Analysis of results of amount of particulate matter in combustion of wood chips and sawdust at nominal and reduced output is realized in the Figure 3 and Figure. 4. Values of PM are 
converted to $10 \%$ reference oxygen in the flue gas according to STN EN 303-5 "Heating boilers. Part 5: Heating boilers for solid fuels, manually and automatically stoked, nominal heat output of up to $500 \mathrm{kW"} \mathrm{[9].}$

During the combustion of wood chips in the first measurement of particulate matter at reduced output was marked by unsatisfactory combustion. The unsatisfactory combustion could be caused by high fuel humidity, which was approximately $50 \%$ at the time of measurement. Based on the results, it can be concluded that, the concentrations of particulate matter in wood chips combustion are significantly higher at the reduced output than at nominal output.

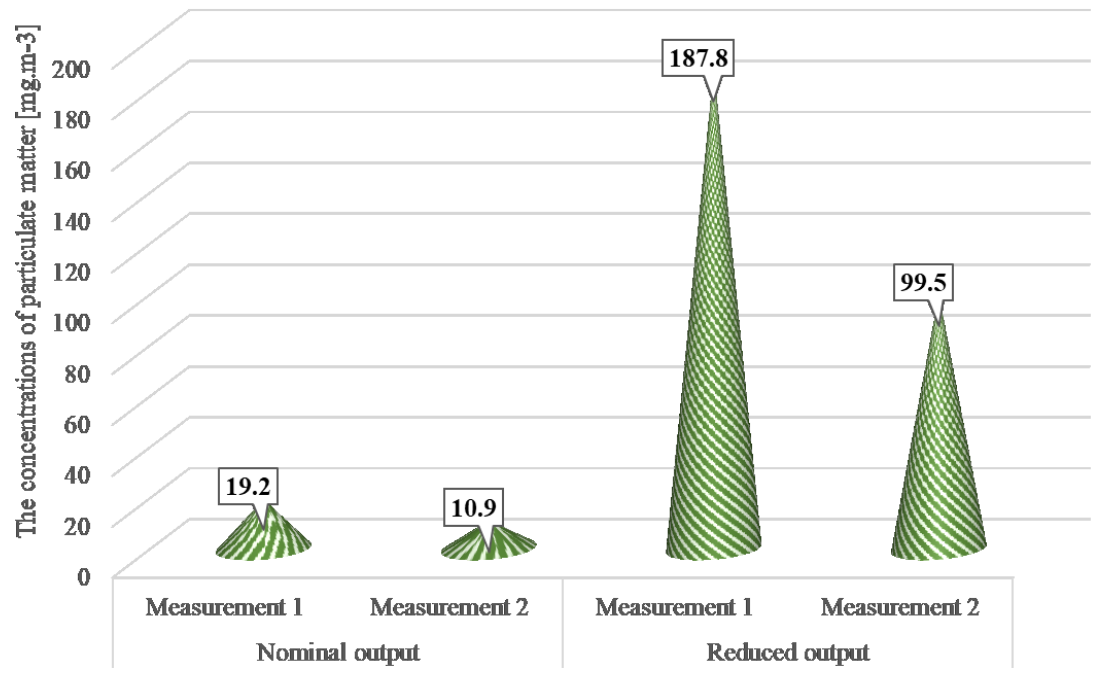

Fig. 3. The graphical analysis of measured concentrations of PM in wood chips combustion.

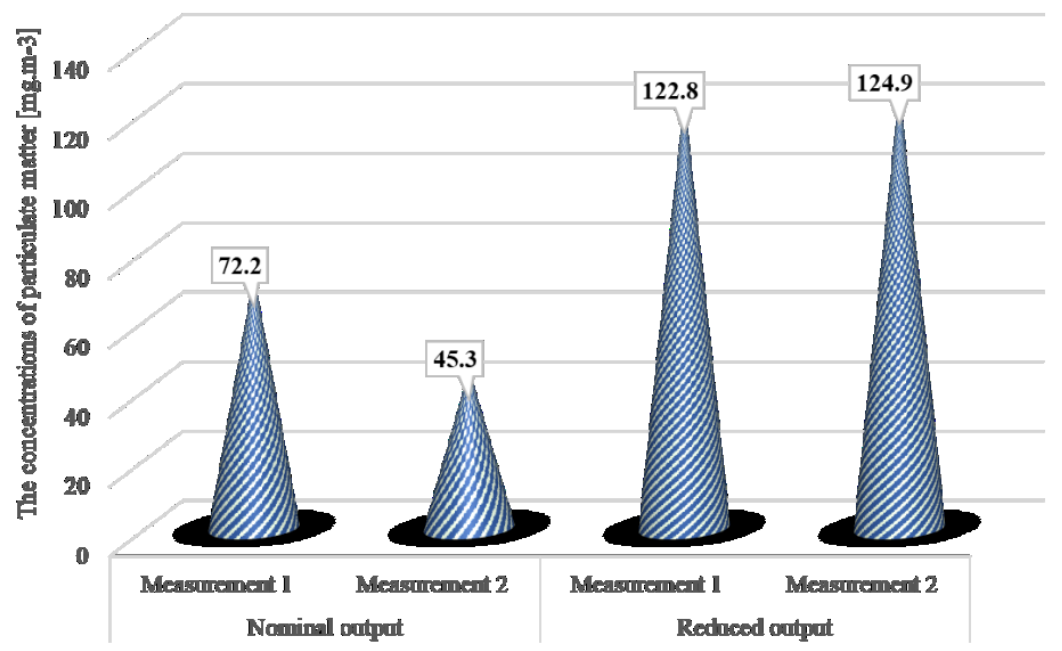

Fig. 4. The graphical analysis of measured concentrations of PM in wood sawdust combustion.

Based on the results, it can be concluded again that, the concentrations of particulate matter in wood sawdust combustion are significantly higher at the reduced output than at nominal output. We can see also a significant increase in PM formation in wood sawdust 
combustion than wood chips combustion. This increase at the nominal output in the flue gas was on average up to $74.4 \%$ higher than that of fuel wood chips.

\section{Conclusion}

Examination of combustion process is important for decreasing concentrations of emissions in our environment, such as particulate matter. This paper examines impact of type of fuel and operation of heat source on PM formation. Based on the results, it can be concluded that the least values of particulate matter were obtained during the wood chips combustion at the nominal output on the experimental heat source. The type of fuel, as well as the operation of the heat source has an impact on formation of particulate matter. In terms of PM formation, wood chips are more suitable fuel like wood sawdust and also the operation of the heat source at reduced output has negative influence on their formation.

This work has been supported by the project VEGA 1/0864/16/7 "Analysis and optimization of the factors entering into the process of burning dendromass in small heat sources".

\section{References}

1. F. Fachinger, F. Drewnick, R. Gieré, S. Borrmann, Atmospheric Environment 158 (2017)

2. A. Banski, L. Dzurenda, Acta Facultatis Xylologiae Zvolen 56, 2 (2014)

3. J. Geffertová, A. Geffert, Acta Facultatis Xylologiae 53, 1 (2011)

4. L. Morawska, J. Zhang, Chemosphere 49 (2002)

5. S. Van Loo, J. Koppejan (eds.) "Handbook of biomass combustion and co-firing". Twenty University Press, Enchede. (2008)

6. M. Holubčík, P. Durčanský, P. Nemec, SGEM 2016 Conference Proceedings, 1 (2016)

7. J. Tissari, Fine particle emissions from residential wood combustion. [online]. Doctoral dissertation. (2008)

8. R. Nosek, M. Holubčík, J. Jandačka, Acta Facultatis Ecologiae: journal of Faculty of Ecology and Environmental Sciences Technical University in Zvolen (2012)

9. STN EN 303-5: Vykurovacie kotly. Čast' 5: Vykurovacie kotly na tuhé palivá s ručným a automatickým prikladaním paliva s menovitým výkonom do $500 \mathrm{~kW}$. Terminológia, požiadavky, skúšanie a označovanie. December (2012)

10. A. Zrak, J. Meško, J. Moravec, R. Nigrovič, D. Kadáš, Journal for Science, Research and Production 16, 1 (2016)

11. P. Nemec, M. Smitka, M. Malcho, Scientific world journal, 2014 (2014)

12. P. Nemec, M. Malcho, J. Jandačka, AIP Conference Proceedings, 1558, (2013) 